\title{
Strategic trade and FDI policies in a unionized industry ${ }^{1}$
}

\section{Domenico Buccella ${ }^{2}$}

\begin{abstract}
This paper analyzes the differences between strategic trade and the competition policies (in the form of inward Foreign Direct Investment) to regulate a unionized monopoly in the domestic country. With decentralized negotiations both policies reduce labour and product market distortions. However the fixed cost for the foreign entrant and the degree of product differentiation determine which policy should be implemented to maximize national welfare, and the cases in which the domestic government can intervene, to achieve a Pareto-improvement.
\end{abstract}

Keywords: strategic trade policy, FDI policy, unionized markets.

JEL codes: F13, J51, L12.

\section{Introduction}

Which policy should a welfare-maximizing government design and implement to regulate an industry characterized by a unionized monopoly structure? This paper precisely analyses this issue within an economy in which national labour market institutions such as unions prevail. Two policies are compared: 1) competition policy and 2) trade policy. The former guarantees market accessibility and contestability; it chiefly depends on the competence of national governments. The latter generates import competition from goods and services produced by foreign companies through their free flow within a country. The rules governing trade policy are, by and large, supranational and mirror the outcome of political issues in multilateral negotiations at the World Trade Organization (WTO). However in line with WTO obligations each member country can apply import tariffs on goods and services provided that their level is lower than the level negotiated in WTO rounds.

As a final effect both policies produce an increase in the degree of product market competition. Nonetheless the effects on national economies differ be-

\footnotetext{
${ }^{1}$ Article received 24 August 2018, accepted 15 December 2018.

2 Department of Economics, Kozminski University, Jagiellońska Street, 57/59, 03-301 Warszawa, Poland, buccella@kozminski.edu.pl.
} 
cause the channels through which those policies work are diverse. To analyze this issue this paper proposes a basic framework. From a status in which, in a closed economy, a monopolist operates in a sector of the economy, its home government must select whether to regulate it via market contestability, i.e. allowing a foreign firm market entry in that sector via Greenfield Foreign Direct Investment (FDI) or via strategic trade policy, allowing imports from a unionized foreign country while setting an optimal tariff. The paper considers a decentralized unionization structure when the foreign firm enters via inward Greenfield FDI, i.e. a decentralized wage setting in which two firm-level unions fix the wages at their respective companies. This assumption reflects real world cases. In fact greenfield site development may be incentivized exactly by the lack of union representation of the local workforce. Moreover FDI gives foreign firms incentives to deviate from industry-wide bargaining agreements by establishing single union plants and non-union agreements: famously Nissan adopted the former strategy at its Sunderland UK plants in 1987 (see e.g. New York Times, 1987).

This paper relates to a vast body of literature that analyses the relationship between trade and investment policies and the national economic outcomes in the presence of unionized labour market institutions. This work is close to the contributions of Naylor $(1998,1999)$. In those articles two identical firms initially produce homogeneous goods for their domestic markets and, under the hypothesis of perfect symmetry in both product and labour markets, they engage in reciprocal dumping when trade costs fall below a threshold value. This leads to a drop in the labour unions' wage claims: intra-industry trade, pushing unions to compete on an international basis in the labour market, corrodes their monopoly power. As economic integration increases (a reduction in trade costs), unions set higher wages because both firms generate higher profits, therefore capturing part of the increased firms' rent. Those papers study the impact of economic integration on wages and unions' outcomes and the interaction between the two economies, exemplified by the unions' strategic behaviour in labour markets.

Dube and Reddy (2013) present a model of the impact of increased product market competition induced by trade liberalization on the income distribution between profits and wages. Those authors show that integration increases the employment cost of wage claims, thereby decreasing bargained wages and the share of oligopoly rents shouldered by workers. This effect is widened due to the existence of strategic complementarities which leads to a race to the bottom. Trade liberalization induces a wage discipline that reduces the negative impact of fiercer competition on firm rents.

On the other hand making use of the Hotelling model, Pagel and Wey (2013) analyze how international market competition affects a union's choice of a wage setting, i.e. uniform or discriminatory. Firms are heterogeneous with regard to international competition. According to the main findings when unions choose 
their wage regimes sequentially, a discriminatory regime is more likely to arise when international competition increases. Nonetheless for intermediate levels of competition a union may decide to opt for a uniform wage regime, even if the rival union adopts a discriminatory regime. When international competition becomes adequately intense both unions reverse their preferences toward the discriminatory regime. Only in the latter case is a societal Pareto-improvement obtained if all unions adopt a uniform wage regime.

A second strand of the literature analyzes the interaction between unionized labour markets and firm activities related to the internationalization of production through FDI (see i.e. Bughin \& Vannini, 1995; Naylor \& Santoni, 2003; Mukherjee \& Broll, 2007; Eckel \& Egger, 2009; Mezzetti \& Dinopoulos, 1991; Zhao, 1995, 1998) to explore the effects on wages and employment, either in a partial or a general equilibrium framework. However, of particular interest within the analysis of this paper, are also the contributions of Lommerud, Meland and Sørgard (2003), Glass and Saggi (2005), and Ishida and Matsushima (2009). Lommerud and others (2003) use a two-country reciprocal dumping model of oligopoly in which only one country is unionized concentrating the analysis on the impact of trade liberalization and wage setting on the firms' location choice, and therefore, the mode that firms choose to serve their relevant markets. In a similar fashion Ishida and Matsushima (2009) investigate the same issue when domestic competition takes place between firms located in a unionized country. Following a different approach from Lommerud and others (2003), Glass and Saggi (2005) determine the endogenous FDI regime equilibrium without considering the effects of trade liberalization. In their international duopoly model trade costs are sufficiently low such that firms may always export their products. The crucial assumption is that both firms require one intermediate product that a local upstream monopolist supplier provides exclusively. The authors show that, under these circumstances, outward FDI can act as a cost-raising strategy. However these works neglect to examine the strategic interaction in the labour markets. In a union-oligopoly context, similar to the one here proposed, Vlassis and Mamakis (2014) find the optimal equilibria that can arise from the implementation of diverse policies by a benevolent social planner in the labour market. Those policies may be in conflict or in common interest with unions' and firms' objectives, while in other cases institutional labour market arrangements appear to be inefficient to induce or deter FDI. Therefore the social planner must find alternative strategic devices. Despite the different approaches, underlying hypotheses and purposes of the analysis, these models chiefly achieve a common result: if firms can invest abroad they will cause a moderation in wage claims. Consequently the unions' position appears to be weakened.

This paper also relates to Vandenbussche and Konings (1998), Vandenbussche (2000), and Buccella (2012). These works investigate the differences between trade and competition policies. However this paper takes a different route from 
the abovementioned contributions regarding several aspects. First, as in Naylor (1998), the foreign wage is not exogenously given in the case of trade policy: in fact, the union in the foreign country endogenously sets its wage, competing over jobs against the union in the home country. Moreover, the goods that the domestic and foreign firms produce are differentiated. Second, the current work explicitly models the presence of tariff barriers and thus the implementation of the strategic trade policy; those features are absent in the analysis of Vandenbussche and Konings (1998) and Vandenbussche (2000). Third, entry is costly in this model. Therefore the size of the fixed cost the entrant faces alters the two policies' practicability.

Recently Mukherjee and Sinha (2016) have investigated how the strategic choice between trade and FDI of a foreign firm to enter a market may affect the welfare of a country. As in the current paper export requires a per-unit trade cost, while FDI requires a fixed investment. In contrast to the common wisdom those authors show that low product market competition levels may increase the overall social welfare. However those authors consider an exogenous (null) marginal cost of production for the competing firms and the domestic (host) government plays no role in incentivizing/discouraging the foreign firm's entry strategy.

The main results of the present paper are as follows. The choice between the two policies for the government depends on the amount of the initial fixed cost for the entrant and the degree of differentiation of the goods. In the case of trade the foreign union can moderate wage demands to allow the foreign firm to penetrate the domestic market. However, with decentralized unions, the home government can enjoy the benefits from designing and incentivizing the inward FDI policy when the fixed cost of the initial investment is comparatively high to improve social welfare, unless the degree of differentiation among products is rather high. In fact, remarkably, the domestic government can partially subsidize the initial investment of the foreign firm, regardless of the degree of product differentiation, to encourage the entry and improve social welfare. The rationale for this result is that more intense competition due to the presence of the foreign firm in the domestic market, exerts downward pressure on prices that benefits consumers by compensating the losses in tariff revenues. On the other hand the domestic government can find it a beneficial practice to hamper the inward FDI when the initial cost of the investment is relatively low and products are close substitutes, favouring import penetration to improve social welfare.

The remainder of the paper is organized as follows. Section 1 presents the basic ingredients of the formal model. Section 2 derives the product market, the wages and home country welfare outcomes under the competition and trade policies. Section 3 analyses the entry decision of the foreign firm. Section 4 investigates the national welfare implications of the competition and trade policies. An outline of future research is presented in the conclusions. 


\section{The model: basic ingredients}

This section builds a partial equilibrium model to investigate the consequences of strategic trade and FDI policy on national welfare to regulate a monopoly industry in the presence of unionized workforce. The present model generalizes Buccella (2012) to the case of differentiated products and FDI. The home country exhibits a monopoly sector. The monopolist produces goods denoted as $q$, using only homogeneous labour, $l$, as a factor of production, with constant returns to scale technology. Each worker produces one unit of output, $l=q$; thus, production and employment levels are identical. The workers in the industry are organized in a monopoly union (see e.g. Haucap \& Wey, 2004; Petrakis \& Vlassis, 2004) that is assumed to be able to control the amount of labour hired in the sector. The supply of labour in the economy is assumed to be adequately large to avoid corner solutions. The unionization structure is characterized by a decentralized wage setting in which wages are set at the firm-level.

The home government aims at introducing competition in the monopoly industry. Two policy options are suitable: 1 ) the trade channel, namely that in which the home incumbent faces import competition in the domestic market from a foreign exporter producing differentiated goods. At the beginning imports equal zero because of a prohibitive tariff. However the home government sets an optimal tariff lower than the prohibitive one to maximize domestic welfare; 2) the competition (investment) channel, with the entry via inward greenfield FDI of a foreign firm in the sector is considered. The foreign entrant faces a fixed cost denoted by $F$. It is assumed that 1 ) no domestic company can disburse the cost of the initial investment, ${ }^{3}$ and 2) the home government can use a lump-sum tax instrument to transfer part (or all) of the extra social surplus generated under FDI vs. export to the foreign firm, thus inducing FDI entry in the domestic market when the foreign firm would have incentives to export. In both cases, the industry market structure shifts from a monopoly to a duopoly. The foreign exporter also faces a monopoly union. Lower scripts 1 and 2 refer to the incumbent and entrant, while $H$ and $F$ denote Home and Foreign respectively.

The model is a five-stage game solved backwards. At the pre-stage of the game the home government designs the policy, either strategic trade or investment, to regulate the monopoly. In the first stage the foreign firm selects the entry mode: exports vs. greenfield FDI. In the second stage the home government implements the policy. In the third stage unions set wages. In the fourth stage firms compete in the relevant home product market, determining production and employment levels. The analysis focuses on the home country.

\footnotetext{
${ }^{3}$ Under the hypotheses of this paper, if there is a potential domestic entrant, the home government will always prefer it to an international one, because the international firm repatriates profits to the country of origin.
} 
First let us consider the benchmark case of monopoly in the home setting. The monopolist produces goods facing the following linear, indirect demand schedule

$$
p_{H}=1-q_{1 H}
$$

where $q_{1 H}$ denotes the incumbent's output, and $p_{H}$ the price. The monopolist's profit maximization problem is

$$
\Pi_{1 H}=\left(1-q_{1 H}-w_{H}\right) q_{1 H},
$$

where $w_{H}$ is the wage set by the home union. Taking as given the monopoly quantity, the home union maximizes the total wage bill

$$
\Omega_{H}=w_{H} q_{1 H} .
$$

Simple calculations leads to $w_{H}=\frac{1}{2}$, and $q_{1 H}=\frac{1}{4}$. Therefore union utility and profits are $\Omega_{H}=\frac{1}{8}, \Pi_{1 H}=\frac{1}{16}$. The measure of the consumers' surplus is

$$
C S_{H}=\frac{q_{1 H}^{2}}{2} .
$$

and equals $C S_{H}=\frac{1}{32}$. Thus the home social welfare is

$$
S W_{H}=\Omega_{H}+\Pi_{1 H}+C S_{H}=\frac{7}{32} .
$$

\section{Competition}

The home government seeks to stimulate competition in the monopoly sector. Therefore home consumers may gain access both to goods produced by the domestic and the foreign company. It follows that the linear inverse demand schedules for the goods are

$$
p_{1 H}=1-q_{1 H}-c q_{2 F} ; \quad p_{2 F}=1-c q_{1 H}-q_{2 F}
$$

where $q_{1 H}$ and $q_{2 F}$ are the incumbent production and imports from the foreign country and $p_{1 H}$ and $p_{2 F}$ are the prices of the domestic incumbent and foreign 
entrant respectively. The parameter $c \in[0,1]$ represents the degree of product differentiation: when $c=0$, the goods are independent, and as $c \rightarrow 1$, the goods become close substitutes.

\subsection{Cournot competition with trade policy}

Stage 4, firms' quantity choices and labour demands with imports

With the trade policy the country opens to imports. Given the inverse demand functions in (6) the profit function of the home incumbent firm is

$$
\Pi_{1 H}=\left(1-q_{1 H}-c q_{2 F}-w_{H}\right) q_{1 H}
$$

while the foreign exporter's profits generated in the home market are

$$
\Pi_{2 F}=\left(1-c q_{1 H}-q_{2 F}-w_{F}-t\right) q_{2 F}
$$

subject to the non-negativity constraint $q_{2 F} \geq 0$, where $w_{F}$ is the foreign union's wage rate. Notice that the foreign exporter is the "entrant" in the home product market via trade. Thus imports have index 2. The foreign exporter faces a tariff $t$ to sell products in the home setting. The home government sets an optimal tariff on imports to extract part of the foreign exporter's rents, getting tariff revenues and maximizing national welfare.

Cournot competition between the two firms in the home product market leads to

$$
q_{1 H}=\frac{\left[2\left(1-w_{H}\right)-c\left(1-t-w_{F}\right)\right]}{4-c^{2}}, q_{2 F}=\frac{\left[2\left(1-w_{F}\right)-c\left(1-w_{H}\right)-2 t\right]}{4-c^{2}},
$$

which also represent the labour demand functions. As expected the standard results $\frac{\partial q_{1 H}}{\partial t}>0$ and $\frac{\partial q_{2 F}}{\partial t}<0$ hold: an increase in the applied tariff increases domestic production and hinders imports.

Stage 3, wage setting

Regarding labour markets wages are interdependent; unions compete against each other over jobs. The utility function is (3) for the home union. Similarly the foreign union's utility function is

$$
\Omega_{F}=w_{F} q_{2 F}
$$


Substituting the Cournot quantities into the home and foreign unions' utility functions the maximization problems are respectively,

$$
\begin{gathered}
w_{H}=\underset{w_{H}}{\arg \max _{H}}\left\{\Omega_{H}=\frac{w_{H}\left[2\left(1-w_{H}\right)-c\left(1-t-w_{F}\right)\right]}{4-c^{2}}\right\} \\
w_{F}=\underset{w_{F}}{\arg \max _{F}}\left\{\Omega_{F}=\frac{w_{F}\left[2\left(1-w_{F}\right)-c\left(1-w_{H}\right)-2 t\right]}{4-c^{2}}\right\} .
\end{gathered}
$$

The solutions lead to the reaction functions

$$
w_{H}=\frac{\left[2-c\left(1-t-w_{F}\right)\right]}{4}, w_{F}=\frac{\left[2(1-t)-c\left(1-w_{H}\right)\right]}{4} .
$$

As expected, $\frac{\partial w_{H}}{\partial w_{F}}>0$ and $\frac{\partial w_{F}}{\partial w_{H}}>0$ : an increase in wages in one firm triggers an increase in the wages of the rival; that is, wages are strategic complements. Moreover, $\frac{\partial w_{H}}{\partial t}>0$ and $\frac{\partial w_{F}}{\partial t}<0$ : an increase in the applied tariff increases protection for the domestic workers and, thus, leads to higher wage demand, while the presence of a tariff induces foreign workers to moderate wage demand to facilitate exports.

Inserting the expressions in (11) into each other, the equilibrium wages are

$$
w_{H}=\frac{\left[8-c^{2}-2 c(1-t)\right]}{16-c^{2}}, w_{F}=\frac{\left[\left(8-c^{2}\right)(1-t)-2 c\right]}{16-c^{2}},
$$

with $\frac{\partial w_{i}}{\partial c}<0, i=H, F$ : as the products become close substitutes, the duopoly rents are reduced; as a consequence, the unions can extract a lower share of those rents.

The non-negativity condition $q_{2 F} \geq 0$ and the equilibrium wages in (12) imply that trade occurs if

$$
\bar{t} \leq 1-\frac{2 c}{8-c^{2}},
$$

which represents the prohibitive tariff: in fact, for $t>\bar{t}$, the tariff is so high that imports are prevented. Differentiation of (13) shows that $\frac{\partial \bar{t}}{\partial c}<0$; as products become close substitutes, the prohibitive tariff decreases and, therefore, a lower tariff is required to hamper imports. 
Stage 2, Strategic trade policy implementation: Social welfare evaluation and the government's optimal tariff

Making use of (12), the expressions for the foreign exporter's wage, quantity, price and profits as well as home wages, production, prices, union utility, profits and consumers' surplus are obtained as function of the degree of product differentiation and the tariff rate. The tariff revenues are

$$
T R_{H}=\frac{t\left[\left(16-2 c^{2}\right)(1-t)-4 c\right]}{\Upsilon},
$$

where $\Upsilon=c^{4}-20 c^{2}+64$. Hence the home government sets the optimal tariff to maximize domestic welfare

$$
S W_{H}=\Omega_{1 H}+\Pi_{1 H}+C S_{H}+T R_{H}
$$

where $C S_{H}=\frac{\left(q_{1 H}^{2}+q_{2 F}^{2}+2 c q_{1 H} q_{2 F}\right)}{2}$. Given the expressions in (14), the government problem is

$$
t=\underset{t}{\arg \max }\left\{S W_{H}=\frac{2\left[8+6 t-7 t^{2}-2 c-c^{2}\left(1+t-t^{2}\right)\right]}{\Upsilon}\right\},
$$

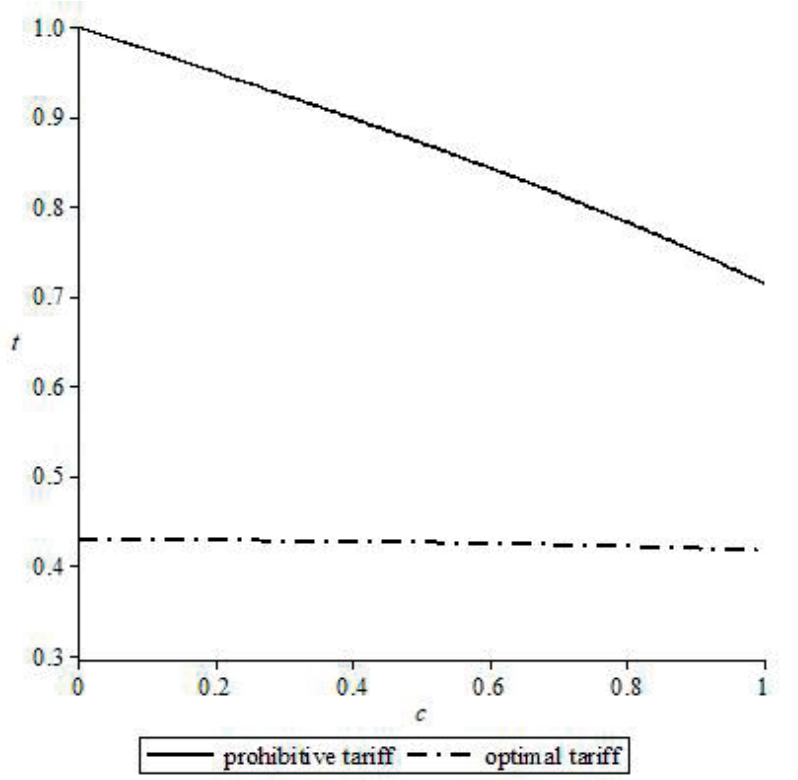

Figure 1. Prohibitive and optimal tariff 
whose solution is

$$
t^{*}=\frac{6-c^{2}}{2\left(7-c^{2}\right)} \text {. }
$$

The optimal tariff set by the home government in (15) depends on the degree of product differentiation. The differentiation of (15) shows that $\frac{\partial t^{\star}}{\partial c}<0$; as products become close substitutes, the duopoly rents of the foreign exporter decrease and the home government sets a lower tariff. Figure 1 reveals that $\forall c \in[0,1), t^{*}<\bar{t}$; there is always an optimal tariff, lower than the prohibitive one, that the home government can apply to extract part of the foreign exporter's rents independent of the degree of product differentiation.

Making use of (15) the relevant equilibrium values are derived, summarized in Table 1. As a consequence, the social welfare under strategic trade policy is

$$
S W_{H}^{S T}=\frac{5 c^{4}+8 c^{3}-72 c^{2}-56 c+260}{2\left(7-c^{2}\right) \Upsilon} .
$$

\subsection{Cournot competition with investment policy}

As mentioned in the introduction, to reflect the practice of multinational companies of opting out of national/sector collective bargaining in favour of company-wide agreements (European Foundation, 2009), the paper considers decentralized firm-level unions in case of FDI.

Stage 4, firms' quantity choices and labour demands with FDI

To regulate monopoly the alternative policy option the government may implement is market contestability allowing the entry of the foreign firm in the domestic market through FDI. The industry shifts from a monopoly to a duopoly. Given the inverse demand functions in (6), the profits of the home incumbent are

$$
\Pi_{1 H}=\left(1-q_{1 H}-c q_{2 F}-w_{1 H}\right) q_{1 H}
$$

while the foreign firm's profits are

$$
\Pi_{2 F}=\left(1-c q_{1 H}-q_{2 F}-w_{2 F}\right) q_{2 F}-F,
$$

where $q_{1 H}$ and $q_{2 F}$ are the incumbent and entrant production levels respectively. To produce in the home country the foreign firm faces a fixed cost, $F$. The home government needs to evaluate whether it should incentivize entry by paying a subsidy to the foreign firm to improve national welfare. 
Cournot competition in the home product market leads to the following output levels

$$
q_{1 H}=\frac{\left[2\left(1-w_{1 H}\right)-c\left(1-w_{2 F}\right)\right]}{4-c^{2}}, q_{2 F}=\frac{\left[2\left(1-w_{2 F}\right)-c\left(1-w_{1 H}\right)\right]}{4-c^{2}} .
$$

with the standard results $\frac{\partial q_{1 H}}{\partial w_{2 F}}>0, \frac{\partial q_{1 H}}{\partial w_{1 H}}<0, \frac{\partial q_{2 F}}{\partial w_{1 H}}>0, \frac{\partial q_{2 F}}{\partial w_{2 F}}<0$ : an increase in the rival firm's wages increases its own production, while an increase in its own wages decreases its own production.

\section{Stage 3, wage setting}

In the presence of a decentralized wage setting structure in the home country firm-level unions operate in the labour market. The union utility functions are

$$
\Omega_{1 H}=w_{1 H} q_{1 H}, \Omega_{2 F}=w_{2 F} q_{2 F}
$$

where $w_{1 H}$ and $w_{2 F}$ are the wages charged by the two home unions (therefore index $H$ for union 2) to the home and foreign firms respectively. Substituting the Cournot quantities into the union utility functions the maximization problems are

$$
\begin{aligned}
& w_{1 H}=\underset{w_{1 H}}{\arg \max _{1 H}}\left\{\Omega_{1 H}=\frac{w_{1 H}\left[2\left(1-w_{1 H}\right)-c\left(1-w_{2 F}\right)\right]}{4-c^{2}}\right\}, \\
& w_{2 F}=\underset{w_{2 F}}{\arg \max _{2 F}}\left\{\Omega_{2 H}=\frac{w_{2 F}\left[2\left(1-w_{2 F}\right)-c\left(1-w_{1 H}\right)\right]}{4-c^{2}}\right\} .
\end{aligned}
$$

The solutions lead to the wage reaction functions in each firm

$$
w_{1 H}=\frac{\left[2-c\left(1-w_{2 F}\right)\right]}{4}, w_{2 F}=\frac{\left[2-c\left(1-w_{1 H}\right)\right]}{4},
$$

yielding the equilibrium wages

$$
w_{1 H}=w_{2 F}=\frac{2-c}{4-c}
$$

with $\frac{\partial w_{1 H}}{\partial c}=\frac{\partial w_{2 F}}{\partial c}<0$ : as the products become close substitutes the oligopoly rents of the firms shrink; therefore the unions extract a lower share of the rents. 


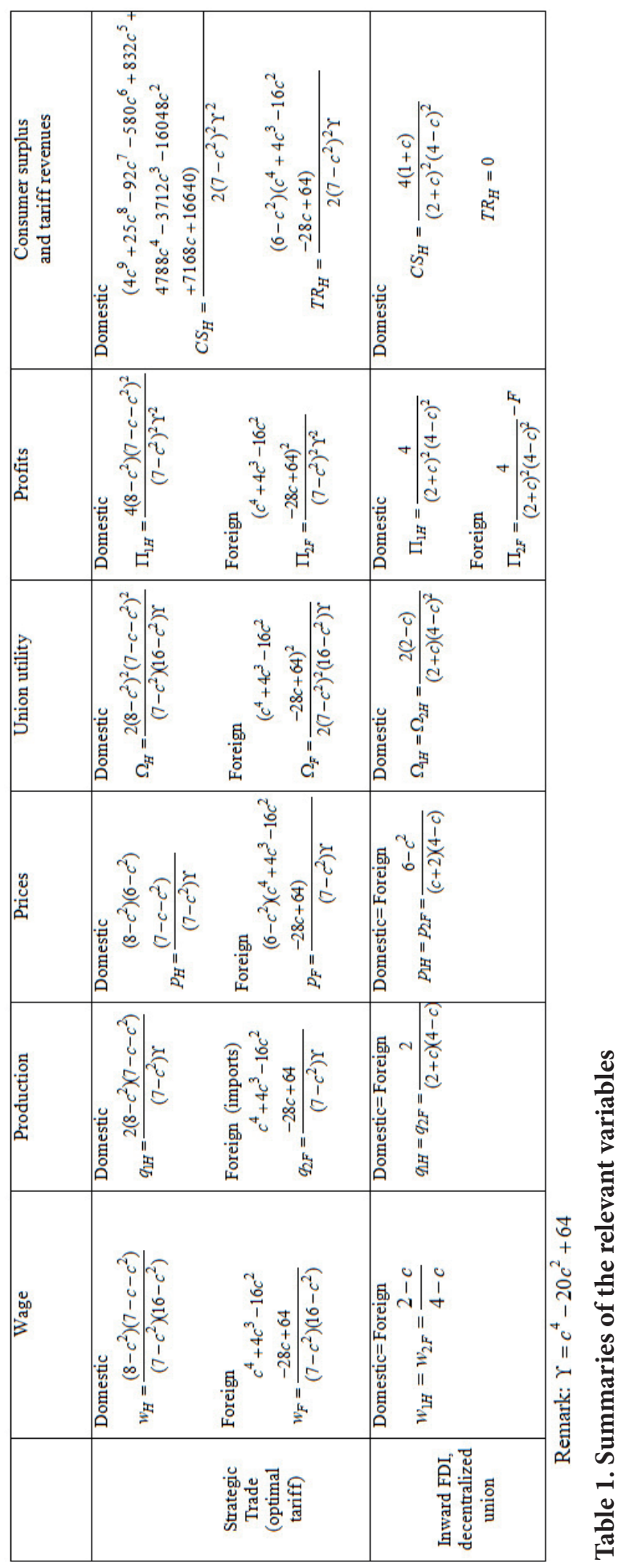


Stage 2, Governments' evaluation of the social welfare

Using (22), the expressions for the home and foreign quantities and price and the foreign firm's profits as well as the home union's utility, profits and consumers' surplus in the presence of decentralized unions are derived and summarized in Table 1. Thus the home government evaluates the social welfare, given by

$$
S W_{H}^{F D I D}=\Omega_{1 H}+\Omega_{2 H}+\Pi_{1 H}+C S_{H}=\frac{4(3-c)}{(2+c)(4-c)^{2}},
$$

to design the most suitable regulation policy in the first stage of the game. Foreign profits are repatriated.

\section{Foreign firm entry decision in the home market}

At stage 1, the foreign firm decides how to enter the home market. The profits for the foreign firm under the FDI and the trade strategy are

$$
\Pi_{2 F}^{F D I D}=\frac{4}{(2+c)^{2}(4-c)^{2}}-F, \Pi_{2 F}^{S T}=\frac{\left(c^{4}+4 c^{3}-16 c^{2}-28 c+64\right)^{2}}{\left(7-c^{2}\right)^{2} \Upsilon^{2}},
$$

where the upper scripts FDID and ST denote "FDI with decentralized unions" and "Strategic trade" respectively. Straightforward payoff comparison leads to the following proposition:

Proposition 1 In the presence of decentralized unions the foreign firm prefers to undertake FDI than to export into the home country if the initial cost of the investment is such that

$$
F \leq \frac{\left(8-c^{2}\right)\left(6-c^{2}\right)\left(3 c^{4}+8 c^{3}-46 c^{2}-56 c+176\right)}{\left(7-c^{2}\right)^{2} \Upsilon^{2}} \equiv F(c)^{F D I D}
$$

Proof: Direct payoffs comparison.

The first region in Figure 2 is defined by the following set of points in the (c,F)-plane: $(c \in(F=0) \mid 0 \leq c \leq 1) \cup F \in(c=0) \mid 0 \leq F \leq .042) \cup F \in(c=1)$ $\left.0 \leq F \leq .0408) \cup F \leq F(c)^{F D I D}\right)$. It is found that, in this region, $\Pi_{2 F}^{F D I D} \geq \Pi_{2 F}^{S T}$; despite the presence of a tariff for any given degree of product differentiation the wages and the fixed costs in the home country are low enough that, for the foreign firm, it is profitable to opt for investing. On the other hand the second region, the set $\left.(F \in(c=0) \mid .042<F) \cup F \in(c=1) \mid .0408<F) \cup F(c)^{F D I D}<F\right)$ characterizes the second region in Figure 2 where $\Pi_{2 F}^{S T}>\Pi_{2 F}^{F D I D}$. The fixed costs of the initial investment are now sufficiently high to make exports in the presence of an optimal tariff more beneficial. 


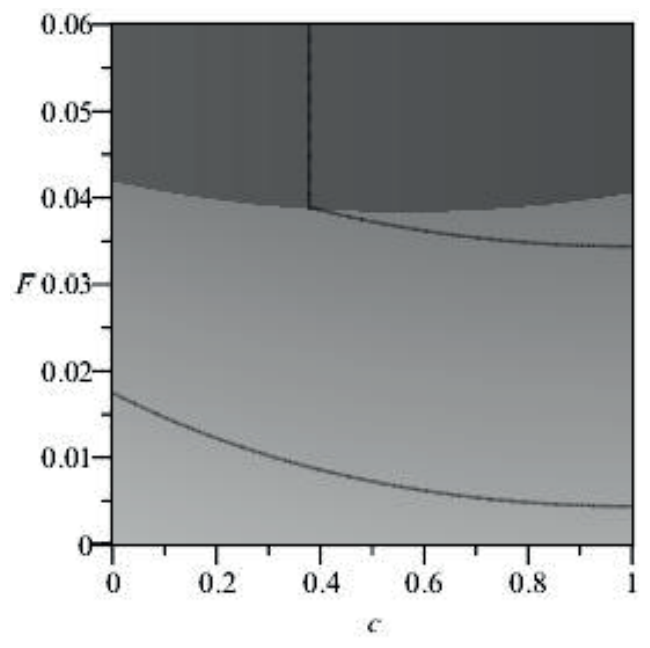

Figure 2. Foreign firm profits

Note: light grey $\Pi_{2 F}^{F D I D} \geq \Pi_{2 F}^{S T}$; dark grey $\Pi_{2 F}^{S T}>\Pi_{2 F}^{F D I D}$

The rationale for this result is as follows. The investment allows the foreign firm to "jump the tariff," and this has the effect of reducing its marginal cost of production. On the other hand, in the presence of inward FDI, the foreign firm pays higher wages (see Table 1) than in the case of trade policy (because the foreign union can moderate wage demands to allow the foreign firm to export in the home country) and this has the opposite effect of increasing the marginal cost of production. Depending on the degree of product differentiation the first effect can overcome (be overcome by) the second, more precisely when goods are extremely and poorly (intermediately) differentiated, generating an U-shaped form of the threshold $F(c)^{F D I D}$.

\section{Government's policy design and implications}

At stage 0 , the Government designs the competition policy. If the workforce in the home setting is organized in firm-level unions the wage level decreases with respect to the monopoly, because unions compete against each other for jobs. In this case the degree of product differentiation affects the equilibrium wage. However, despite the fact that wages decrease with respect to monopoly, the utility of workers, given by the sum of the union utilities, increases because the employment level in the home market increases. The price of the final products decreases because of the greater intensive market competition, and this implies increasing consumer surplus. The profits of the former monopolist lessen. The social welfare is higher than in the case of autarky. 
The key factor for the home government when designing the investment policy is the willingness of the foreign firm to bear the initial cost of the investment to enter into the domestic market and thus the size of $F$. Conversely, in the case of the strategic trade policy, monopoly regulation via imports exposes home workers to wage competition from abroad. Hence, the wage level in the home setting lowers: import competition puts home wages under pressure. It follows that the strategic trade policy also induces wage moderation; however by stimulating competition through imports, it reduces the home employment with respect to both monopoly (unless product are close substitutes, i.e. for $c=0.817)$ and investment policy. On the other hand the investment policy with decentralized union moderates wages more than the strategic trade policy (the presence of a tariff partially protects domestic workers) but leads to a higher employment level. Figure 3 exemplifies these findings.

Both policies reduce the price of the domestically produced goods with respect to monopoly. However, the price in the home market under the investment policy is lower than under the strategic trade policy because the wage moderation effect is more intense. Given that the foreign firm produces in the home market the final prices of the products are equal. With regard to home workers the comparison of the union utility payoffs in Table 1 shows that, $\forall c \in[0,1]$, their position improves more with the investment policy in the presence of decentralized unions than with the strategic trade policy. The rationale for this result is as follows. The implementation of the investment policy with decentralized unions lowers the workers' wage rate with respect to the strategic trade policy; nonetheless, it creates more jobs. The impact on the union utility of the employment effect more than overcomes the losses due to a lower wage. The final effect is an increase of the utility of unions.

Given that $\Pi_{1 H}=\left(x_{1 H}\right)^{2}$ and $\Pi_{2 F}=\left(x_{2 F}\right)^{2}$, the analysis conducted on production and employment holds for the profits the domestic and foreign firms gen-
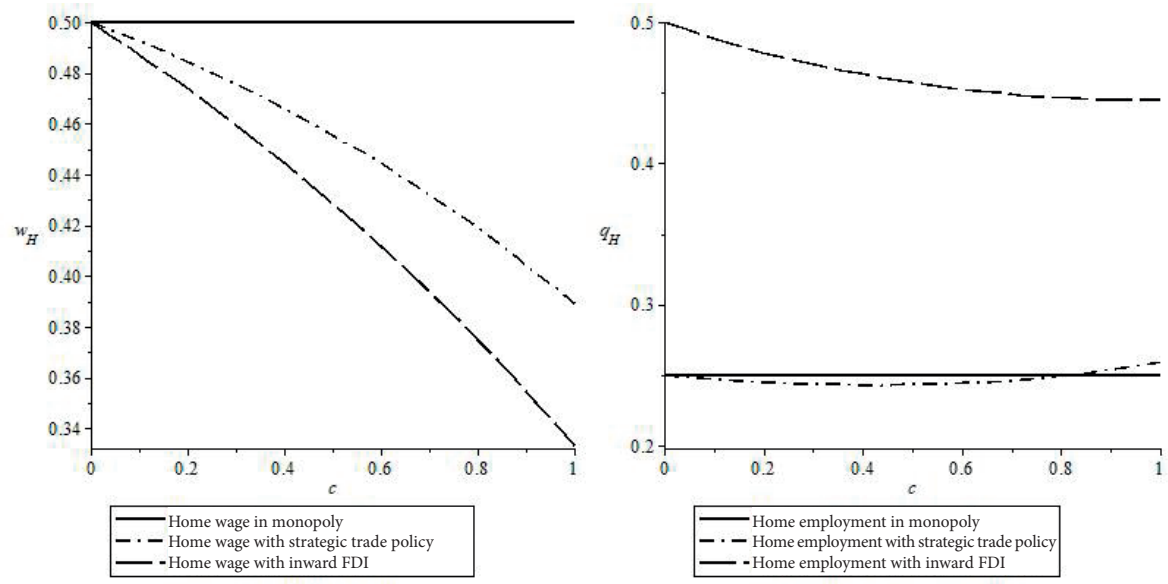

Figure 3. Left box: home wages; right box: home employment 
erate in the home setting. Moreover consumers unambiguously benefit from the investment policy both because of a demand higher than monopoly and the final prices being lower than monopoly and trade policy price.

The home government evaluates the overall national welfare to design the most advantageous regulation policy. The foreign firm's fixed cost of entry and the degree of product differentiation play a crucial role. Figure 4, left box, shows the home welfare in the $(c, F)$ - space.

The vertical axis reports the values of the fixed cost in the range $F \in[0,1 / 16]$, in which the upper limit, $F^{\max }=1 / 16$ is the gross profit level of the foreign firm when it invests in the home country in the presence of independent products, representing the maximum subsidy the home government would pay to the foreign firm.

A direct payoffs comparison shows that $S W^{F D I D}-F \geq S W^{S T}$ if

$$
F \leq \frac{\left.3 c^{5}+4 c^{4}-64 c^{3}+16 c^{2}+300 c-304\right)}{2(4-c)\left(7-c^{2}\right) \Upsilon} \equiv F^{\tau} .
$$

Further analytical inspection reveals that, for $c \in[0,1] \cup F \in[0,1 / 16]$, $F^{\tau}-F(c)^{F D I D}<F^{\max }$ (see Figure 4, right box), with $F^{\tau}=F(c)^{F D I D}$ for $c=0.811$ : therefore the home government, unless goods are close substitutes, has at its disposal a certain amount of resources to subsidize partially the foreign investor.

Making use of the expressions for $F(c)^{F D I D}$ and $F^{\tau}$ it is possible to construct Figure 5, characterized by four regions. In region I, given that $F \leq F(c)^{F D I D}$,
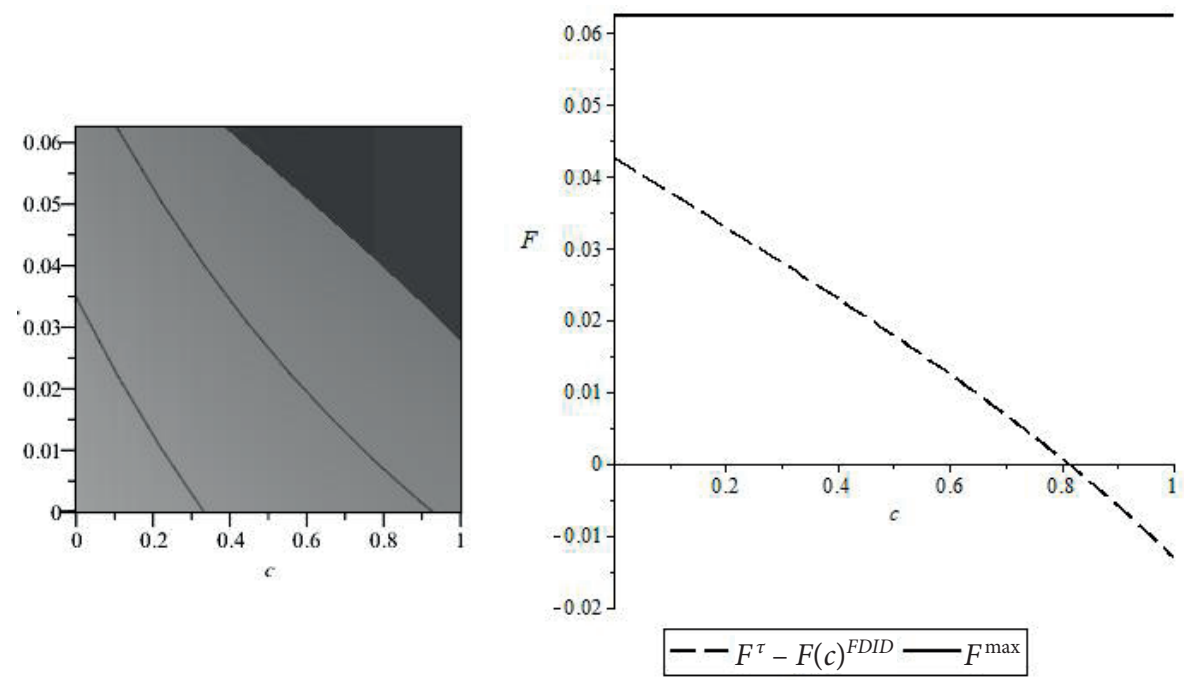

Figure 4. Left box: home social welfare, decentralized unions; right box: subsidization feasibility

Note: light grey $S W_{H}^{F D I D} \geq S W_{H}^{S T}$; dark grey $S W_{H}^{S T}>S W_{H}^{F D I D}$ 


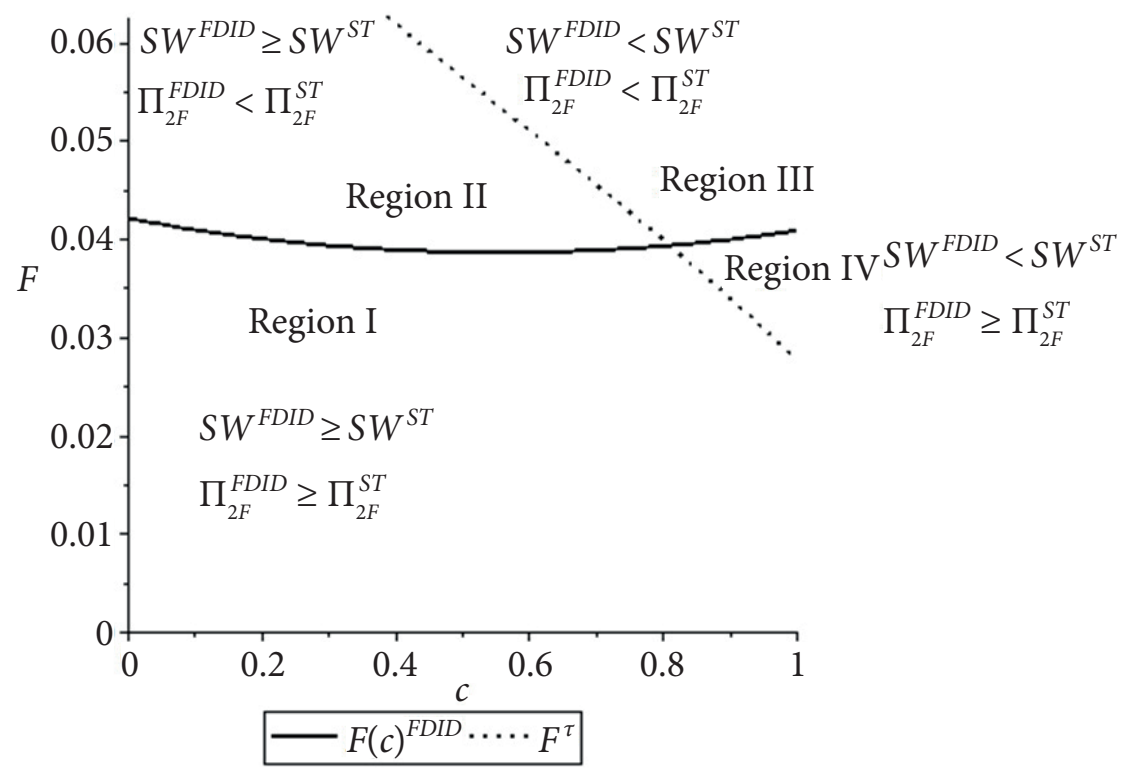

Figure 5. Home government-foreign firm common interest/conflict of interests, and policy interventions

the foreign firm decides to invest because $\Pi_{2 F}^{F D I D} \geq \Pi_{2 F}^{S T}$. At the same time the home social welfare is such that $S W^{F D I D} \geq S W^{S T}$ because $F \leq F^{\tau}$. As a consequence the foreign firm and the home government have a common interest toward FDI; the home government does not have to provide the foreign firm with subsidies to promote entry.

In region II the foreign firm decides to export to the home country because $F(c)^{F D I D}<F$, and therefore $\Pi_{2 F}^{S T}>\Pi_{2 F}^{F D I D}$. However, the home social welfare is such that $S W^{F D I D} \geq S W^{S T}$ because $F \leq F^{\tau}$. Therefore the foreign firm and the home government have a conflict of interest with regard to FDI. Nonetheless, given that $F^{\tau}-F(c)^{F D I D}<F^{\max }$, the home government can now partially subsidize the foreign firm to incentivize entry as far as $F^{\tau}-F(c)^{F D I D} \geq 0$ which applies in the range $c \in[0,0.811]$.

In region III the foreign firm exports to the home country because $\Pi_{2 F}^{F D I D} \geq \Pi_{2 F}^{S T}$, and concurrently the home social welfare is such that $S W^{S T}>S W^{F D I D}$ because $F^{\tau}<F$. As a consequence the foreign firm and the home government have again a common interest, but this time toward trade, and the home government does not have to intervene.

Finally, in region IV the foreign firm invests in the home country but the home social welfare is higher under trade, i.e. $S W^{S T}>S W^{F D I D}$ : a conflict of interest between the foreign firm and the home government exists. However, given that for $c \in(0.811,1], F^{\tau}-F(c)^{F D I D}<0$, the home government can now 
ask for additional fees related to starting a business to discourage entry in the form of FDI. These results are summarized in the following proposition.

Proposition 2. In the relevant $(c, F)$ - space there are two areas in which the home government can intervene to achieve a Pareto-improvement of the social welfare: 1) Region II, where it can opt to subsidize partially the initial cost of the investment of the foreign firm (incentivizing inward FDI), and 2) Region IV where it can ask for additional fees to the foreign firm to start business (discouraging inward FDI).

As Figure 4, right box, depicts, $d F^{\tau} / d c<0$ : as products become close substitutes the duopoly rents decrease. Thus, the profitability for the firms in the industry lowers and thus the size of the fixed cost that the foreign entrant can sustain also decreases. In the presence of decentralized unions the home government can find designing and incentivizing the investment policy to be advantageous: more intense competition due to the presence of the foreign firm in the home market triggers a reduction in price that benefits consumers so as to outweigh the losses in tariff revenues. ${ }^{4}$

\section{Conclusions}

This paper has analyzed the effects on domestic welfare of two different policies that a government can apply to introduce competition in a unionized monopolized industry: competition and strategic trade policies. Both policies shift the product market from monopoly to duopoly: the former through market contestability and the latter via import competition. In the presence of decentralized, firm-specific wage settings the competition policy allows the domestic unions to expand employment; however the wage level reduces. On the other hand, trade openness leads to a softened wage moderation because the home union competes over jobs with the foreign one; however, it suffers from a reduction in employment. As a result the impact of the two policies on price, employment, and welfare differs.

The domestic government selects between the two policies depending on the magnitude of the initial fixed cost for the foreign entrant and the degree of product differentiation. In the presence of decentralized unions the domestic government can find it a beneficial practice to design and incentivize entry via the inward FDI policy when the cost of the initial investment is comparatively

\footnotetext{
${ }^{4}$ In a Supplement, available upon request from the author, it is investigated the case of an industry-wide union in the home country which sets wages simultaneously although separately in the domestic and foreign firms. The qualitative results are confirmed with the only difference that, in the presence of an industry-wide union the domestic government can opt to subsidize the foreign firm if the goods are not close substitutes in order to improve social welfare and therefore it has less room to subsidize the foreign firm to enter the domestic market.
} 
high to improve social welfare, unless the degree of product differentiation is rather high. On the other hand, the domestic government can find it beneficial to discourage the inward FDI when the cost of the initial investment is relatively low and the degree of product differentiation is extremely high, favouring import penetration to improve social welfare.

The findings of this work relate to the simplifying hypothesis that the home and foreign unions set unilateral wages. A framework in which unions and firms bargain wages is a straightforward extension to check the robustness of the model to obtain a better evaluation of the policy effects on the national economy. Moreover, Bertrand competition in the product market may alter some of the results. Furthermore, a robustness check for different production technologies (i.e. a convex cost function) is called for. Related to the latter point the introduction of capital in the production function and therefore an analysis of technological spill-overs that may also benefit the firms in the host country in the case of entry via FDI, is another promising subject of investigation. Finally this work has considered a simple lump-sum instrument policy to finance the entry subsidy. However, the government could use alternative policies to incentivize FDI, such as labour market legislation (allowing for instance for non-unionization of the new plants) or tax breaks. Both have been observed empirically. Those issues are left for further research.

\section{References}

Buccella, D. (2012). Unionized monopoly regulation: Strategic trade vs. domestic competition policies. Economics Bulletin, 32(1), 932-940.

Bughin, J., \& Vannini, S. (1995). Strategic direct investment under unionized oligopoly. International Journal of Industrial Organization, 13, 127-145.

Dube, A., \& Reddy, S. (2013). Threat effects and trade: Wage discipline through product market competition. Journal of Globalization and Development, 4(2), 213-252.

Eckel, C., \& Egger, H. (2009). Wage bargaining and multinational firms. Journal of International Economics, 77(2), 206-214.

European Foundation for the Improvement of Living and Working Conditions. (2009). Multinational companies and collective bargaining. Retrieved from http://www.eurofound.europa.eu/eiro/studies/tn0904049s/tn0904049s.htm

Glass, A. J., \& Saggi, K. (2005). Exporting versus direct investment under local sourcing. Review of World Economics, 141( 4), 627-647.

Haucap, J., \& Wey, C. (2004). Unionisation structure and innovation incentives. Economic Journal, 114, 149-165.

Ishida, J., \& Matsushima, N. (2009). Domestic competition and foreign direct investment in unionized oligopoly. The Institute of Social and Economic Research Discussion Paper No. 757. Osaka: Osaka University.

Lommerud, K. E., Meland, F., \& Sørgard, L. (2003). Unionised oligopoly, trade liberalisation and location choice. Economic Journal, 113(490), 782-800. 
Mezzetti, C., \& Dinopoulos, E. (1991). Domestic unionization and import competition. Journal of International Economics, 31, 79-100.

Mukherjee, A., \& Broll, U. (2007). Welfare effects of foreign direct investment: cost saving vs. signaling and welfare. Journal of Economics, 90(1), 29-43.

Mukherjee, A., \& Sinha, U. B. (2016). Competition, foreign direct investment and welfare. Economics Letters, 139, 43-45.

Naylor, R. (1998). International trade and economic integration when labour markets are generally unionised. European Economic Review, 42, 1251-1267.

Naylor, R. (1999). Union wage strategies and international trade. Economic Journal, 109(452), 102-115.

Naylor, R., \& Santoni, M. (2003). Foreign direct investment and wage bargaining. Journal of International Trade and Economic Development, 12(1), 1-18.

New York Times. (1987, June 2). Nissan's revolution in Britain.

Pagel, B., \& Wey, C. (2013). Unionization structures in international oligopoly. Labour, 27(1), 1-17.

Petrakis, E., \& Vlassis, M. (2004). Endogenous wage-bargaining institutions in oligopolistic industries. Economic Theory, 24, 55-73.

Vandenbussche, H. (2000). Trade policy versus competition policy: Substitutes or complements?. De Economist, 148, 625-642.

Vandenbussche, H., \& Konings, J. (1998). Globalisation and the effects of national versus international competition on the labour market: Theory and evidence from Belgian firm level data. World Economy, 21, 1151-1177.

Vlassis, M., \& Mamakis, S. (2014). Optimal strategies in unionized oligopoly and inward FDI (Department of Economics Working Paper Series No. 1402). University of Crete. Zhao, L. (1995). Cross-hauling direct foreign investment and unionized oligopoly. European Economic Review, 39, 1237-1253.

Zhao, L. (1998). The impact of foreign direct investment on wages and employment. Oxford Economic Papers, 50, 284-301. 